\title{
Genotoxicity and antigenotoxicity assessment of shiitake (Lentinula edodes (Berkeley) Pegler) using the Comet assay
}

\author{
CK Miyaji $1^{1}$, BQ Jordão ${ }^{1}$, LR Ribeiro ${ }^{2,3}$, AF Eira $^{2}$ and IMS Cólus ${ }^{1}$ \\ ${ }^{1}$ Universidade Estadual de Londrina (UEL), Londrina, Paraná, Brazil. \\ ${ }^{2}$ Universidade Estadual Paulista (UNESP), Campus Botucatu, São Paulo, Brazil. \\ ${ }^{3}$ Universidade Luterana do Brasil (ULBRA), Canoas, Rio Grande do Sul, Brazil.
}

\begin{abstract}
The mushroom shiitake (Lentinula edodes (Berkeley) Pegler) is been widely consumed in many countries, including Brazil, because of its pleasant flavor and reports of its therapeutic properties, although there is little available information on the genotoxicity and/or antigenotoxicity of this mushroom. We used the Comet assay and HEp-2 cells to evaluate the in vitro genotoxic and antigenotoxic activity of aqueous extracts of shiitake prepared in three different concentrations $(0.5,1.0$ and $1.5 \mathrm{mg} / \mathrm{mL})$ and three different temperatures $\left(4,22\right.$ and $\left.60{ }^{\circ} \mathrm{C}\right)$, using methyl methanesulfonate (MMS) as a positive control and untreated cells as a negative control. Two concentrations (1.0 and $1.5 \mathrm{mg} / \mathrm{mL}$ ) of extract prepared at $4{ }^{\circ} \mathrm{C}$ and all of the concentrations prepared at $22 \pm 2$ and $60{ }^{\circ} \mathrm{C}$ showed moderate genotoxic activity. To test the protective effect of the three concentrations of the extracts against the genotoxicity induced by methyl methanesulfonate, three protocols were used: pre-treatment, simultaneous-treatment and post-treatment. Treatments were repeated for all combinations of preparation temperature and concentration. Two extracts $\left(22 \pm 2{ }^{\circ} \mathrm{C} 1.0 \mathrm{mg} / \mathrm{mL}\right.$ (simultaneous-treatment) and $4^{\circ} \mathrm{C} 0.5 \mathrm{mg} / \mathrm{mL}$ (post-treatment)) showed antigenotoxic activity.
\end{abstract}

Key words: shiitake, Comet assay, HEp-2 cells; genotoxicity, antigenotoxicity.

Received: March 17, 2003; Accepted: September 15, 2003.

\section{Introduction}

The single cell gel electrophoresis assay (Comet) is a well-established highly sensitivity genotoxicity test that has been used to detect a broad spectrum of DNA damage (Fairbairn et al., 1995; Anderson et al., 1998). In the alkaline version of this test, DNA strand breaks and alkali-labile sites are detected and the extent of DNA migrations indicates the amount of DNA damage in the cell (Singh, 2000). According to Tice (1995) and Fairbairn et al. (1995), the alkaline assay has been extensively used to assess the repair of single-strand breaks and the DNA damage induced by several agents and under a variety of experimental conditions (in vivo and in vitro). This assay can also be applied to examine the genotoxic and protective potential of several natural products.

The identification of antimutagenic agents present in the diet represents an effective strategy to influence or inhibit pathological processes resulting from exposure to an increasing number of mutagenic and/or carcinogenic sub-

Send correspondence to IMS Cólus. Universidade Estadual de Londrina, Departamento de Biologia Geral - CCB, Caixa Postal 6001, 86051-970, Londrina,PR, Brazil. E-mail address: colus@ sercomtel.com.br. stances present in the environment (Wattemberg, 1983; Wattemberg, 1985; Ferguson, 1994).

Shiitake is an edible mushroom, highly appreciated due to its nutritional and medicinal properties, which has been reported to be of use in the reduction of arterial pressure and blood cholesterol levels as well as in the prevention of heart diseases and cancer (Wasser and Weis, 1999). However, few studies have been performed regarding the genotoxic and antigenotoxic potential of shiitake, and although Grüter et al. (1991) found that methanolic extracts of shiitake showed no mutagenic activity on bacteria the effects of shiitake on eukaryotic organisms remains unknown. Using an in vivo micronucleus (MN) test and cyclophosphamide and N-ethyl-N-nitrosourea as mutagens, Lima et al. (2001) found that shiitake strain LE 96/17 exhibited antimutagenic activity.

The objective of the study described in this paper was to investigate aqueous extracts of the shiitake mushroom (Lentinula edodes (Berkeley) Pegler), strain LE 96/17 for possible genotoxic or antigenotoxic effects on epidermoid carcinoma human larynx cells (HEp-2) exposed to the alkylant agent methyl methanesulfonate (MMS) using the alkaline version of the Comet assay. 
This study is part of a larger and more extensive research program to investigate distinct $L$. edodes lineages for genotoxic and antigenotoxic activity and identify those lineages having the most desirable characteristics for consumption; a further aim being to characterize and purify chemical components from these lineages and evaluate them in genotoxicity tests. Studies with crude aqueous extracts are appropriate because they best represents the form in which shiitake is consumed. In addiction, with the extracts it is possible to maintain the possible interactions among different chemical components, which effects could be not detected in studies that use only purified components.

\section{Materials and Methods}

\section{Cell lines and culture conditions}

Epidermoid carcinoma human larynx cells (HEp-2) were kindly provided by Prof. R.E.C. Linhares (Microbiology Department, State University of Londrina, Paraná Brazil). Cells were grown at $37{ }^{\circ} \mathrm{C}$ in $10 \mathrm{~mL}$ D-MEM/Ham F-10 (1:1) medium (Sigma) supplemented with 10\% fetal calf serum (Cultilab), antibiotics (penicillin $0.06 \mathrm{~g} / \mathrm{L}$ and streptomycin $0.10 \mathrm{~g} / \mathrm{L}$ - Sigma) and HEPES (2.38 g/L Serva) in $25 \mathrm{~cm}^{2}$ culture flasks (Nunc).

\section{Chemicals}

As recommended by the International Workshop on Genotoxicity Test Procedures (Tice et al., 2000), for the positive control we used the mutagenic alkylating agent methyl methanesulfonate (MMS, Sigma; CAS: 66-27-3) dissolved and diluted in phosphate-buffered saline (PBS) to give a final concentration in the culture medium of $4 \times 10^{-4} \mathrm{M}$ MMS in all cases.

Agarose LMP (low melting point, CAS: 9012-36-6, Gibco BRL) at $0.5 \%(\mathrm{w} / \mathrm{v})$ and agarose NMP (normal melting point, CAS: $9012-36-6$, Gibco BRL) at $1.5 \%(\mathrm{w} / \mathrm{v})$ were dissolved in $\mathrm{Ca}^{2+}$ and $\mathrm{Mg}^{2+}$-free PBS.

\section{Shiitake strains}

For our experiments we used Lentinula edodes (Berkeley) Pegler (shiitake) strain LE 96/17 produced and supplied by the Faculty of Agronomic Sciences, UNESP, Botucatu, SP, Brazil.

\section{Preparation of aqueous extracts of shiitake and HEp-2 cell treatment protocol}

Shiitake powder was produced from strain LE 96/17 by dehydrating the recently collected fruiting bodies (the edible portion of the fungus) to about $7 \%$ humidity and grinding them to a powder which was storing at room temperature protected from light until use.

To prepare aqueous suspensions we added $5 \mathrm{~g}$ of shiitake powder to $200 \mathrm{~mL}$ of deionized distilled water and agitated the suspension for $5 \mathrm{~min}$, after which it was allowed to stand for different periods of time at different temperatures as follows: low temperature (LT), $4{ }^{\circ} \mathrm{C}$ for $1 \mathrm{~h}$ before filtering; room temperature (RT), $22 \pm 2{ }^{\circ} \mathrm{C}$ for $2 \mathrm{~h}$ before filtering and high temperature (HT), $60^{\circ} \mathrm{C}$ for $5 \mathrm{~min}$ and filtered after cooling for $15 \mathrm{~min}$ at room temperature. The suspensions were filtered first through filter-paper and then through a $0.20 \mu \mathrm{m}$ bacteriological filter (Millipore) and the extracts stored at $-20{ }^{\circ} \mathrm{C}$ for further use. The aqueous extracts were applied to cell cultures at final concentrations equivalent to $0.5,1.0$ and $1.5 \mathrm{mg} / \mathrm{mL}$ of culture medium.

Three totally independent experiments were performed to determine the genotoxicity and antigenotoxicity of the different concentrations shiitake extracts. Positive (MMS) and negative (untreated cells) control groups were also included in the analysis. All experiments were carried out, in triplicate, using HEp- 2 cells between the $3^{\text {rd }}$ and $8^{\text {th }}$ culture passage after thawing. For the experiments, $10^{6}$ cells were seeded into tissue-culture flasks, incubated for one cycle ( $24 \mathrm{~h}$ ) in complete D-MEM/Ham F-10 medium, washed with PBS and then submitted to one of the following treatments in serum-free medium: a) MMS for $2 \mathrm{~h}$ (positive control); b) shiitake extract for $2 \mathrm{~h}$ (extract treatment); c) extract plus MMS for $2 \mathrm{~h}$ (simultaneous-treatment); d) shiitake extract for $2 \mathrm{~h}$ before washing the cells and adding MMS for $2 \mathrm{~h}$ (pre-treatment with extract); e) MMS for $2 \mathrm{~h}$ before washing the cells and adding shiitake extract for $2 \mathrm{~h}$ (post-treatment with extract). The cells were washed twice with PBS (pH 7.4) after each treatment. Treatments "b" to " $\mathrm{e}$ " were repeated for all combinations of preparation temperature $\left(4,22 \pm 2\right.$ or $\left.60^{\circ} \mathrm{C}\right)$ and concentration $(0.5,1.0$ or $1.5 \mathrm{mg} / \mathrm{mL}$ ). Treatment "a" was the positive control, treatment "b" the genotoxicity experiment and treatments "c", "d" and "e" the antigenotoxicity experiments. Cells from flasks that did not receive any of these treatments were used as the negative control.

\section{Single cell gel electrophoresis}

The procedures reported by Singh et al. (1988) were used with minor modifications as described by Speit and Hartmann (1999). Briefly, a base layer of 1.5\% NMP agarose was placed on a microscope slide and $10 \mu \mathrm{L}$ of the HEp-2 test cells (which had been treated as described in "a" to "e" above), suspended in $120 \mu \mathrm{L}$ of $0.5 \%$ LMP agarose at $37^{\circ} \mathrm{C}$, were then spread on the base layer. A coverslip was added and the agarose was allowed to solidify at $4{ }^{\circ} \mathrm{C}$ for $15 \mathrm{~min}$, after which the coverslip was gently removed and the slide immersed in freshly made lysing solution composed by $89 \mathrm{~mL}$ a stock solution $(2.5 \mathrm{M} \mathrm{NaCl}, 100 \mathrm{mM}$ EDTA, $10 \mathrm{mM}$ Tris $\mathrm{pH} 10.0$ and $1 \%$ sodium lauryl sarcosine) plus $10 \mathrm{~mL}$ of DMSO, $1 \mathrm{~mL}$ of Triton X-100; $\mathrm{pH}$ 10.0 at $4{ }^{\circ} \mathrm{C}$ for at least $1 \mathrm{~h}$, protected from light. At the end of the lysing period, slides were transferred to an electrophoresis box containing a high $\mathrm{pH}(>13.0)$ buffer $(300 \mathrm{mM}$ $\mathrm{NaOH}, 1 \mathrm{mM}$ EDTA) and incubated at $4{ }^{\circ} \mathrm{C}$ for $20 \mathrm{~min}$ to allow the DNA to unwind. A current of $25 \mathrm{~V}(1.0 \mathrm{~V} / \mathrm{cm}$, $300 \mathrm{~mA}$ ) was applied for $20 \mathrm{~min}$, after which, the slides 
were submerged in a neutralization buffer $(0.4 \mathrm{M}$ Tris- $\mathrm{HCl}$, $\mathrm{pH} 7.5$ ) for $15 \mathrm{~min}$, dried at room temperature and fixed in $100 \%$ ethanol for $10 \mathrm{~min}$.

The slides were stored overnight, briefly rinsed in distilled water, stained with $20 \mathrm{mg} / \mathrm{mL}$ ethidium bromide and covered with a coverslip. The stained nucleoids were immediately evaluated at $400 \mathrm{X}$ magnification using a Nikon fluorescence microscope fitted with a 515-560 nm excitation filter and a $590 \mathrm{~nm}$ barrier filter.

\section{Scoring procedures}

For each treatment, the extent and distribution of DNA damage indicated by the Comet assay were evaluated by examining 50 randomly selected and non-overlapping cells on the slides (i.e. 150 cells per treatment).

On each slide, the cells were visually scored and allocated to one of four classes ( $0,1,2$ and 3$)$ according to the tail size as follows: class 0 , undamaged, no tail; class 1 , a short tail with a length smaller than the diameter of the head (nucleus); class 2, tail length between 1 and 2 times the diameter of the head; and class 3 , maximally damaged, with a long tail more than twice the diameter of the head. The few comets observed with no head and those with almost all the DNA in the tail, or with a very wide tail, were excluded from the analysis since they could represent dead cells (Hartmann and Speit, 1997). The total score for 50 comets was obtained by multiplying the number of cells in each class by the damage class, according the formula: Total score $=\left(0 \times \mathrm{n}_{0}\right)+\left(1 \mathrm{x} \mathrm{n}_{1}\right)+\left(2 \mathrm{x} \mathrm{n}_{2}\right)+\left(3 \mathrm{x} \mathrm{n}_{3}\right)$, where $\mathrm{n}=$ number of cells in each class analyzed. Thus, the total score could range from 0 to 150 .

The percentage reduction in the comet score in the treatments with shiitake extracts showing antigenotoxicity was calculated according to Manoharan and Banerjee (1985) and Waters et al. (1990) using the formula:

Reduction $(\%)=\frac{\text { mean score in } \mathrm{A}-\text { mean score in } \mathrm{B}}{\text { mean score in } \mathrm{A}-\text { mean score in } \mathrm{C}} \times 100$

where A is the group of cells treated with MMS (positive control), B the group of cells treated with the shiitake extract plus MMS and $\mathrm{C}$ is the negative control.

\section{Statistical analysis}

The mean scores were calculated from the three independent experiments for each treatment. The KruskalWallis Analysis of Variance on Ranks $(p<0.05)$ test followed by the Dunn's Multiple Comparisons Test were used for comparing the means of each treatment with their negative control in the genotoxicity assessment and positive control in the assessment of reduced genotoxicity.

\section{Results}

\section{Genotoxicity}

Table 1 and Figure 1 show the Comet assay results for the effects of shiitake aqueous extracts after $2 \mathrm{~h}$ treatment of HEp- 2 cells. The $4{ }^{\circ} \mathrm{C} 0.5 \mathrm{mg} / \mathrm{mL}$ extract showed no genotoxic activity, since the mean score was not statistically different from that of the negative control. However,

Table 1 - Comet assay scores for HEp-2 cells treated with three different concentrations of shiitake aqueous extracts prepared at three different temperatures for evaluation of genotoxicity. Three replicates were made for each experiment and 50 nuclei were scored per repetition $(n=150$ cells/group).

\begin{tabular}{|c|c|c|c|c|c|}
\hline \multirow[t]{2}{*}{ Treatments } & \multicolumn{4}{|c|}{ Number of cells with Comet class } & \multirow{2}{*}{$\begin{array}{c}\text { Scores } \\
(\text { mean } \pm \text { s.d. })\end{array}$} \\
\hline & 0 & 1 & 2 & 3 & \\
\hline Negative control & 80 & 58 & 11 & 1 & $27.67 \pm 1.53^{\mathrm{a}}$ \\
\hline $\begin{array}{l}\text { Positive control } \\
\text { (MMS) at } 4 \times 10^{-4} \mathrm{M}\end{array}$ & 16 & 95 & 25 & 14 & $62.33 \pm 3.21^{b}$ \\
\hline \multicolumn{6}{|c|}{ Shiitake extract (mg/mL) } \\
\hline \multicolumn{6}{|c|}{ Low temperature $\left(4^{\circ} \mathrm{C}\right)$} \\
\hline 0.5 & 78 & 58 & 12 & 2 & $29.33 \pm 3.05^{\mathrm{a}}$ \\
\hline 1.0 & 48 & 81 & 19 & 2 & $41.67 \pm 4.16^{\mathrm{ab}}$ \\
\hline 1.5 & 49 & 80 & 20 & 1 & $41.00 \pm 8.18^{\mathrm{ab}}$ \\
\hline \multicolumn{6}{|c|}{ Room temperature $\left(22 \pm 2^{\circ} \mathrm{C}\right)$} \\
\hline 0.5 & 50 & 84 & 15 & 1 & $36.33 \pm 4.72^{\mathrm{ab}}$ \\
\hline 1.0 & 45 & 87 & 15 & 3 & $42.00 \pm 2.64^{\mathrm{ab}}$ \\
\hline 1.5 & 33 & 85 & 26 & 6 & $51.64 \pm 3.78^{a b}$ \\
\hline \multicolumn{6}{|c|}{ High temperature $\left(60^{\circ} \mathrm{C}\right)$} \\
\hline 0.5 & 57 & 72 & 16 & 5 & $39.67 \pm 4.51^{\mathrm{ab}}$ \\
\hline 1.0 & 24 & 111 & 13 & 2 & $47.67 \pm 2.31 \mathrm{ab}$ \\
\hline 1.5 & 53 & 66 & 22 & 9 & $44.33 \pm 2.08^{\mathrm{ab}}$ \\
\hline
\end{tabular}

MMS: Methyl methanesulfonate. Means with the same letter do not differ statistically at the level of $5 \%$. s.d.: standard deviation. 


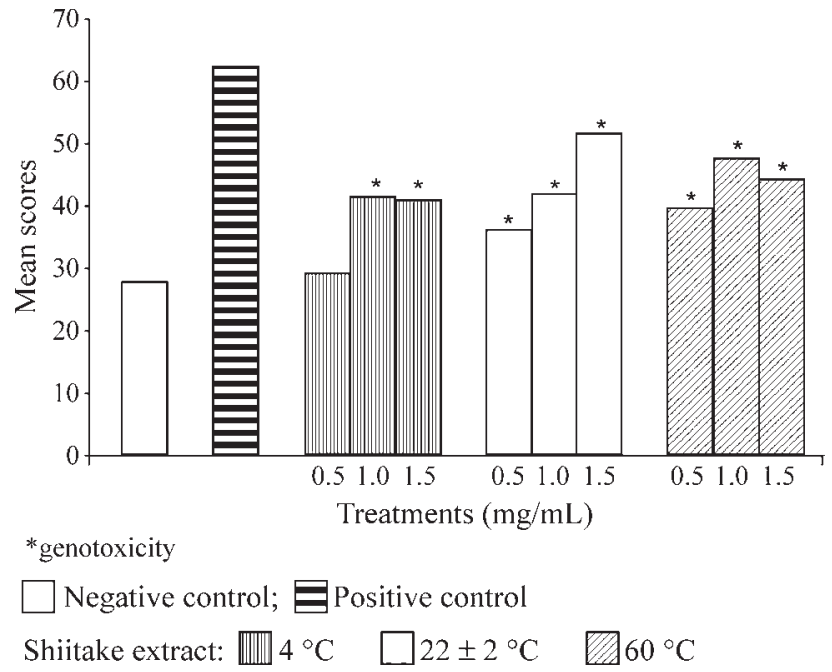

Figure 1 - Evaluation of genotoxicity by the Comet assay after treatment of HEp-2 cells with three aqueous extracts of shiitake $(0.5,1.0$ and 1.5 $\mathrm{mg} / \mathrm{mL})$ prepared at three different temperatures $\left(4,22 \pm 2\right.$ and $\left.60{ }^{\circ} \mathrm{C}\right)$. Data represents Comet assay mean scores.

the $4{ }^{\circ} \mathrm{C} 1.0$ and $1.5 \mathrm{mg} / \mathrm{mL}$ extracts and all the extracts prepared at $22 \pm 2$ and $60{ }^{\circ} \mathrm{C}$ showed some genotoxic action, although the values were intermediate between those of the negative and positive controls.

\section{Antigenotoxicity}

The antigenotoxic activity of the extracts was evaluated using three protocols (simultaneous-treatment, pretreatment with extract and post-treatment with extract), the comet scores of which were compared to the scores obtained for the DNA damaging agent MMS. Table 2 and Figure 2 show the mean scores obtained in all protocols using three different preparation temperatures and concentrations of shiitake extracts (individual values for each repetition are not shown but were very similar).

A protective activity of the aqueous extracts was detected in the $22 \pm 2{ }^{\circ} \mathrm{C} 1 \mathrm{mg} / \mathrm{mL}$ simultaneous-treatment and in the $4{ }^{\circ} \mathrm{C} 0.5 \mathrm{mg} / \mathrm{mL}$ post-treatment experiments. The values of the mean scores obtained after treatment of the cells with the other shiitake aqueous extracts were lower but not statistically different from that observed with MMS alone. For all the extracts, the percentage reduction in the comet score in the treatments with shiitake extracts showing antigenotoxic activity was calculated independently of the protective level (Table 2).

\section{Discussion}

\section{Genotoxicity assessment}

Research using the Ames test to assess the genotoxicity of edible or medicinal mushrooms has produced conflicting results (Sterner et al., 1982a; Sterner et al., 1982b; Grüter et al., 1991).

Our results show that, except for the $4{ }^{\circ} \mathrm{C} 0.5 \mathrm{mg} / \mathrm{mL}$ extract, all of the shiitake extracts evaluated presented a low level of genotoxicity, the values obtained in cells treated with shiitake extracts being intermediate between those obtained in the untreated control group and the group treated with the known mutagen MMS (Table 1; Figure 1).

The fact that the $4{ }^{\circ} \mathrm{C} 0.5 \mathrm{mg} / \mathrm{mL}$ extract showed no genotoxicity is not sufficient to indicate that this concentration is not genotoxic, since the $0.5 \mathrm{mg} / \mathrm{mL}$ extracts prepared at $22 \pm 2$ and $60^{\circ} \mathrm{C}$ showed a low-level of genotoxicity. In our study, we found no dose-response relationship regarding the genotoxic activity of shiitake in HEp-2 cells, which supports the findings of Morales et al. (1990) who found no dose-response relationship when evaluating the mutagenic effects of some edible mushrooms on bacteria.

Analyzing the comet class distribution shown in Table 1 for the treatments with MMS and shiitake aqueous extracts it is clear that cells with class 1 damage (minimal damage) were most prevalent and that cells with class 3 (maximum damage) were rare, that is, many cells presented few damage and few cells presented many damage. Therefore, the mushroom extracts caused moderated damage. This moderate genotoxicity appears to be related not only to the lower concentration of shiitake but also to effect of the preparation temperature on the active factors of Shiitake, since low comet scores were observed with those extracts prepared at the lowest temperatures.

Sterner et al. (1982a) reported that the heating and conservation conditions during the processing of mushrooms can have a great influence on the biological activities of the mushrooms and Morales et al. (1990) detected slightly higher mutagenic activity in frozen mushrooms than in fresh ones, contrasting with the data presented in our present paper (Table 1; Figure 1). Chang (1996) considers that the mushrooms in general have several components with diverse biological activities and that these activities can vary according to how the mushrooms are prepared and consumed, while Grüter et al. (1991) suggest that a mutagen detectable in extracts may be unstable under normal digestion conditions, not be absorbed by the gastrointestinal tract or, alternatively, be activated as a toxic substance by the digestive processes.

Taken together, our findings show that the risks or benefits associated with the consumption of shiitake should be further investigated. The genotoxic activity of shiitake extracts detected in this study suggests the occurrence of different temperature-dependent pathways for the mutagenic agent present in the mushroom, and this could have practical implications for the preparation of shiitake.

\section{Antigenotoxicity assessment}

The interpretation of the results of the present study regarding the antigenotoxicity of the aqueous extract of shiitake is complex, since the extracts seem to have exerted their protective effects by more than one mechanism of action, which, according to Gebhart (1992), is not uncommon for mushrooms. 


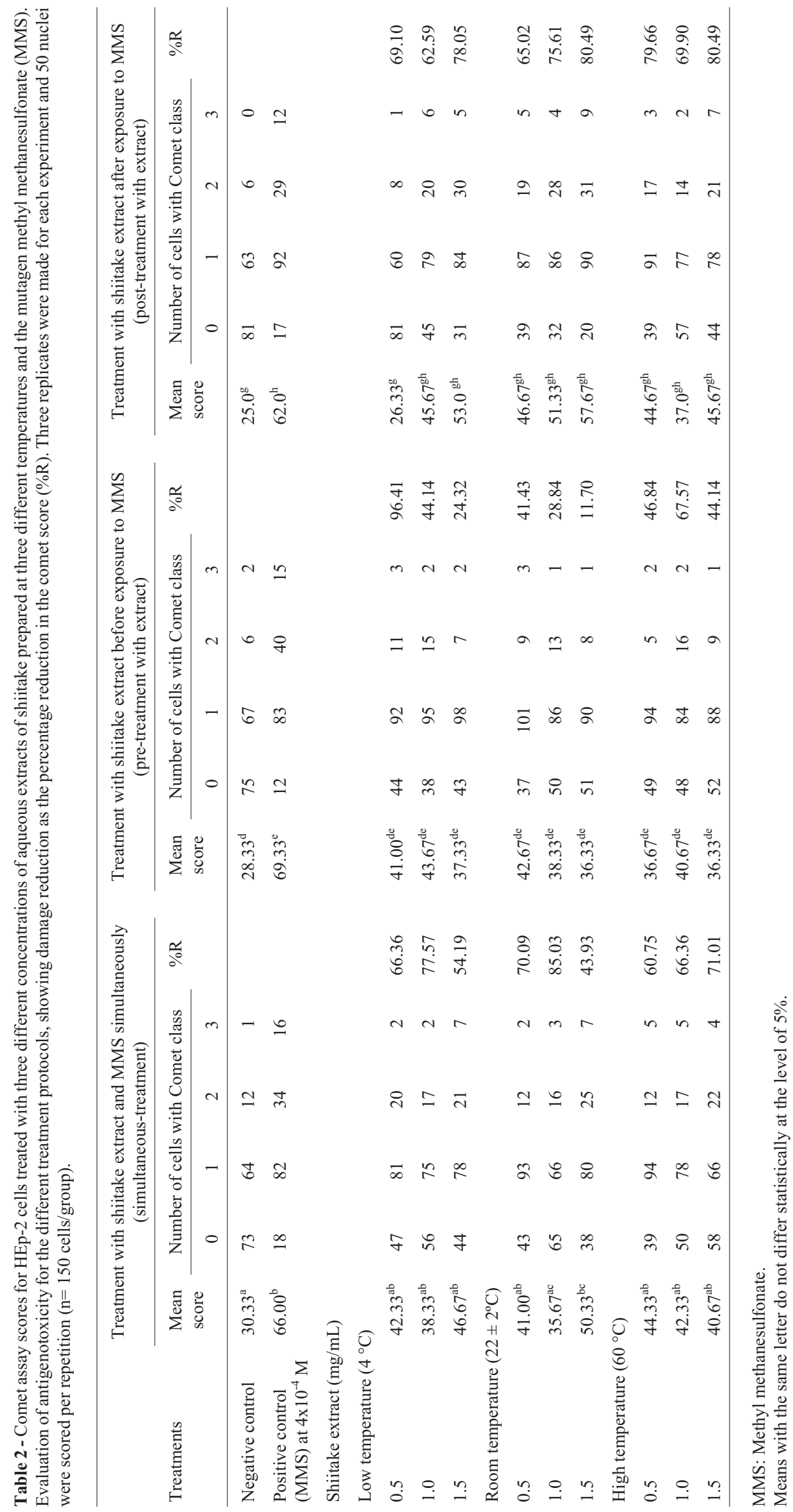



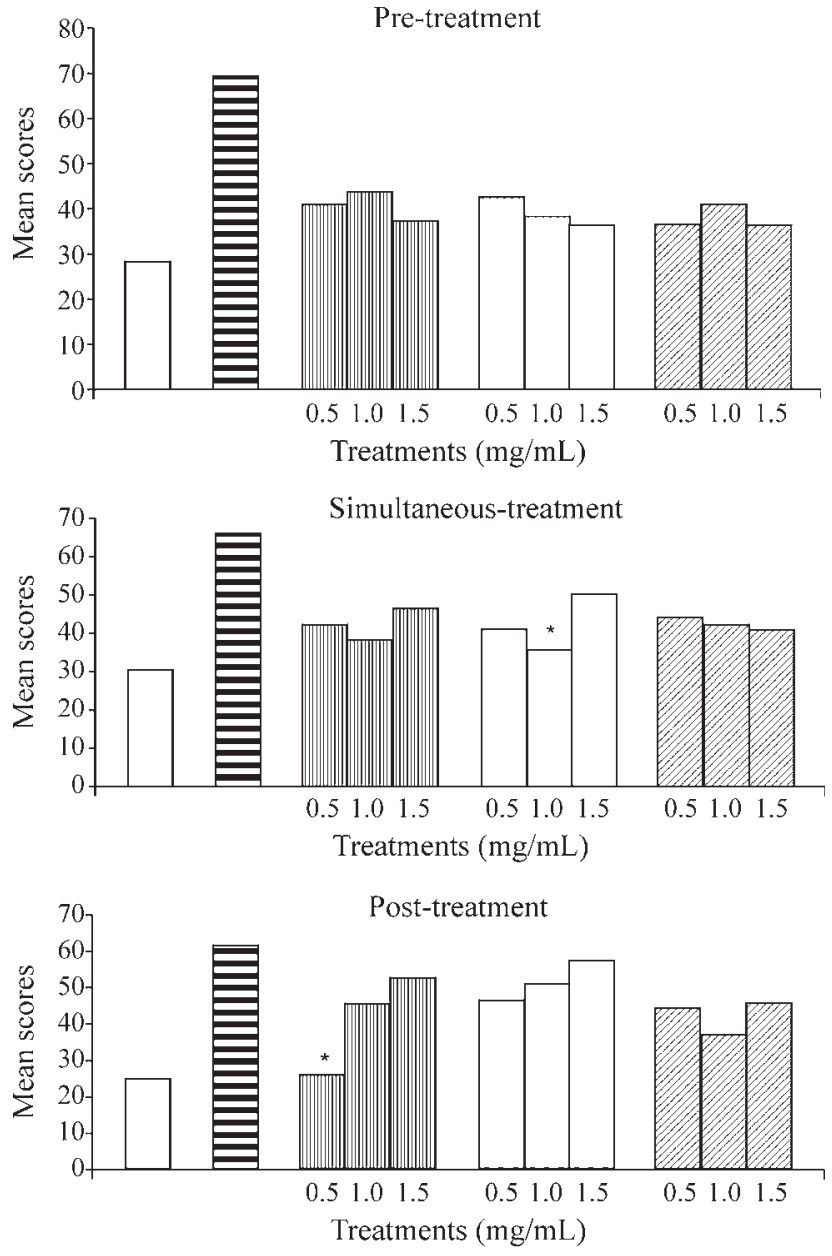

*antigenotoxicity

Negative control; $叉$ Positive control

Shiitake extract: 孟 $4{ }^{\circ} \mathrm{C} \quad \square 22 \pm 2{ }^{\circ} \mathrm{C} \quad 60^{\circ} \mathrm{C}$

Figure 2 - Evaluation of antigenotoxicity by the Comet assay after treatment of HEp-2 cells with three aqueous extracts of shiitake $(0.5,1.0$ and $1.5 \mathrm{mg} / \mathrm{mL})$ prepared at three different temperatures $\left(4,22 \pm 2\right.$ and $\left.60^{\circ} \mathrm{C}\right)$. Three different protocols were used: simultaneous-treatment; pre-treatment and post-treatment. Data represents Comet assay mean scores.

Pre-treatment of the HEp-2 cells with shiitake extracts two hours before treatment with the mutagen MMS revealed no statistically significant protection attributable to the extracts (Table 2; Figure 2), although the percentage reduction in comet score (\%R) was between 60 and $80 \%$. Shi et al. (2002) also used a Comet assay and a similar protocol to investigate $L$. edodes aqueous extracts prepared at 20 and $100^{\circ} \mathrm{C}$ for genoprotector effects on hydrogen peroxide damaged Raji cells, but found no significant protective effect.

According to Kuroda et al. (1992), the mechanism of bio-antimutagenesis is normally detected when the protocol of post-treatment relative to the mutagen is used. In our study, except for the $4{ }^{\circ} \mathrm{C} 0.5 \mathrm{mg} / \mathrm{mL}$ extract, the majority of the extracts tested presented low efficiency in the posttreatment protocol (Table 2; Figure 2), even considering that the $4{ }^{\circ} \mathrm{C} 0.5 \mathrm{mg} / \mathrm{mL}$ extract showed the lowest mean comet score and the highest percentage reduction in comet score of all the treatments used. It seems that the $4{ }^{\circ} \mathrm{C}$ $0.5 \mathrm{mg} / \mathrm{mL}$ extract would be the most appropriate to consume since it appeared to cause no genotoxic effects on the HEp-2 cells (Table 1)

In simultaneous-treatments antimutagenic agents may act as desmutagens by chemically or enzymatically inactivating mutagens, or inhibiting the activation of promutagens (Kuroda et al., 1992). Our experiments were performed in vitro without the addition of microsomal enzymes (which can deactivate toxic chemicals), and the fact that the $22 \pm 2{ }^{\circ} \mathrm{C} 1.0 \mathrm{mg} / \mathrm{mL}$ extract showed antigenotoxicity action against MMS (Table 2; Figure 2) may indicate that this extract chemically inactivated MMS. The other extracts presented a moderate protector effect, although, statistically, the comet scores were not reduced to the levels of the untreated control (Table 2; Figure 2).

The results obtained in this study indicate that the active ingredient of $L$. edodes was present and effective in the extracts prepared at 4 and $22 \pm 2{ }^{\circ} \mathrm{C}$ but at the temperature at which shiitake is frequently consumed $\left(60^{\circ} \mathrm{C}\right)$ it presented no protective effect. The active antimutagenic factor detected in the mushroom Lentinula edodes may be heatlabile (Shi et al., 2002 and Kada, 1981 (apud Grüter et al.,1990)), although the situation is unclear because Grüter et al. (1990) state that several mushrooms have heatresistant factors that reduce the mutagenicity of potent carcinogenic agents such as aflatoxin $\mathrm{B}_{1}$ and benzo[a]pyrene in S. typhimurium.

The polysaccharide lentinan, one of the components obtained by the purification of shiitake, is very different from the whole mushroom, which leads to doubts whether consuming the whole mushroom has any preventative or therapeutic value, and if it does, what would be the ideal form in which to consume it and what would be the most effective dose (Chang, 1996). Research has shown that there was considerable reduction in lentinan content when shiitake was stored for 7 days at $20^{\circ} \mathrm{C}$, whereas no alteration in lentinan content was observed when the mushrooms were stored for 5 days at $5{ }^{\circ} \mathrm{C}$ or for 7 days at $1{ }^{\circ} \mathrm{C}$ (Minato et al., 1999). We believe that the lentinan content remained constant in our study because the extract was prepared from recently collected fruit bodies which had been dried to about $7 \%$ humidity and powdered before storing at room temperature protected from light.

According to Lehmann et al. (2000), some modulators that exert protective effects in a certain situation can become deleterious when the genotoxic agent or parameter being analyzed is modified. The protective effects of the shiitake extracts observed in the present study in HEp-2 cells were obtained in relation to the damage caused by the monofunctional alkylant MMS (which acts directly on DNA bases and on the phosphate backbone causing a broad spectrum of DNA lesions). The alkylation followed by 
depurination can lead to single strand breaks (SSB) in the DNA which can be detected by Comet test (Sanderson and Shield, 1996; Helbig and Speit, 1997).

Our in vitro results are supported by the work of Lima et al. (2001) who used the micronucleus test to evaluate the shiitake strain LE 96/17 in mice and observed an anticlastogenic effect against cyclophosphamide and N-ethyl$\mathrm{N}$-nitrosourea. Taken together, these results indicate that antigenotoxic compounds can occur in shiitake strain LE 96/17 and can protect mammalian cells, both in vitro and in vivo, from the effects of some alkylating agents, although additional studies are necessary with other types of genotoxic agents (preferably not alkylants) to elucidate for a better understanding of the protective mechanism of shiitake extracts.

\section{Acknowledgments}

We thank Prof. José C. Soeiro for useful discussion regarding statistical analysis; the technical assistance of Mr. Dário P. Tormena and the excellent grammar review done by Dra. Angela Mehta. This study was supported by the Brazilian agencies Coordenação de Aperfeiçoamento de Pessoal de Nível Superior (CAPES), Fundação de Amparo à Pesquisa do Estado de São Paulo (FAPESP) and by the Universidade Estadual de Londrina (UEL), Brazil.

\section{References}

Anderson D, Yu T-W and McGregor DB (1998) Comet assay as indicator of carcinogen exposure. Mutagenesis 13:539-555.

Chang R (1996) Functional properties of edible mushrooms. Nutrition Reviews 54:S91-S93.

Fairbairn DW, Olive PL and O'Neill KL (1995) The Comet assay: a comprehensive review. Mutat Res 339:37-59

Ferguson LR (1994) Review antimutagens as cancer chemopreventive agents in the diet. Mutat Res 307:395-410.

Gebhart E (1992) Anticlastogenicity in cultured mammalian cells. Mutat Res 267:211-220.

Grüter A, Friederich U and Würgler FE (1990) Antimutagenic effects of mushrooms. Mutat Res 231:243-249.

Grüter A, Friederich U and Würgler FE (1991) The mutagenicity of edible mushroom in a histidine-independent bacterial test system. Food and Chem Toxicol 29:159-165.

Hartmann A and Speit G (1997) The contribution of citotoxicity to DNA effects in the single cell gel test (Comet assay). Toxicol Lett 10:183-188.

Helbig R and Speit G (1997) DNA effects in repair-deficient V79 Chinese hamster cells studied with the Comet assay. Mutat Res 377:279-286.

Kada T (1983) Environmental and biological factors suppressing induction of mutagens. Toxicology Forum 6:580-589.

Kuroda Y, Jain AK, Tezuka H and Kada T (1992) Antimutagenicity in cultured mammalian cells. Mutat Res 267:201-209.

Lehmann M, Graf U, Reguly ML and Andrade HHR (2000) Interference of Tannic acid on the genotoxicity of mitomicyn C, methyl methanesulfonate and Nitrogen mustard in somatic cells of Drosophila melanogaster. Environ Mol Mutagen 36:195-200.

Lima, PLA, Delmanto RD, Sugui MM, Eira AF, Salvadori DMF, Speit G and Ribeiro LR (2001) Lentinula edodes (Berk.)
Pegler (shiitake) modulates genotoxic and mutagenic effects induced by alkylating agents in vivo. Mutat Res 496:23-32.

Manoharan K and Banerjee MR (1985) $\beta$-Carotene reduces sister chromatid exchange induce chemical carcinogens in mouse mammary cells in organ culture. Cell Biol Int Rep 9:783789.

Minato K, Mizuno M, Terai H and Tsuchida H (1999) Autolysis of Lentinan, an antitumor polysaccharide, during storage of Lentinus edodes, shiitake mushroom. J Agric Food Chem 47:1530-1532.

Morales P, Bermúdez E, Sanz B and Hernández PE (1990) A study of the mutagenicity of some commercially canned Spanish mushrooms. Food Chem Toxicol 9:607-611.

Sanderson BJ and Shield AJ (1996) Mutagenic damage to mammalian cells by therapeutic alkylating agents. Mutat Res 35:41-57.

Shi Y-I, James AE, Benzie IFF and Buswell JA (2002) Mushroom-derived preparation in the prevention of $\mathrm{H}_{2} \mathrm{O}_{2}$-induced oxidative damage to cellular DNA. Teratog, Carcinog Mutagen 22(2):103-111.

Singh NP (2000) Microgels for estimation of DNA strand breaks, DNA protein crosslinks and apoptosis. Mutat Res 455:111127.

Singh NP, McCoy MT, Tice RR and Schneider EL (1988) A simple technique for quantification of low levels of DNA damage in individual cells. Exp Cell Res 175:184-191.

Speit G and Hartmann A (1999) The Comet assay (single cell gel test) - a sensitive genotoxicity test for the detection of DNA damage and repair. In: Henderson DS (ed) Methods in molecular biology, 113 DNA-repair protocols: eukaryotic systems. Humana Press Inc., Totowa, pp 203-212.

Sterner O, Bergman R, Kihlberg E, Magnusson G, Nilsson L, Wickberg B and Zimerson E (1982a) Mutagens in larger fungi. I. 48 species screened for mutagenic activity in the Salmonella/ microsome assay. Mutat Res 101:269-281.

Sterner O, Bergman R, Frenzén C, Kesler E and Nilsson L (1982b) Mutagens in larger fungi. II. The mutagenicity of commercial pickled Lactarius necator in the Salmonella assay. Mutat Res 104:233-237.

Tice RR (1995) The single cell gel: Comet assay: a microgel electrophoretic technique for detection of DNA damage and repair in individual cells. In: Phillips DH and Venitt S (eds) Environmental mutagenesis. Bios Scientific Publishers Ltd. Oxford, pp 315-339.

Tice RR, Agurell E, Anderson D, Burlinson B, Hartmann A, Kobayashi H, Miyamae Y, Rojas E, Ryu JC and Sasaki YF (2000) Single cell gel/Comet assay: guidelines for in vitro and in vivo genetic toxicology testing. Environ Mol Mutagen 35:206-221.

Wasser SP and Weis AL (1999) Therapeutic effects of substances occurring in higher basidiomycetes mushrooms: a modern perspective. Crit Rev Immunol 19:65-96.

Waters MD, Brady AL, Stack HF and Brockman HE (1990) Antimutagenicity profiles for some model compounds. Mutat Res 238:57-85.

Wattemberg LW (1983) Inhibition of neoplasia by dietary constituents. Cancer Res 43:2448s-2453s.

Wattemberg LW (1985) Chemoprevention of cancer. Cancer Res 45:1-8.

Editor: Carlos F.M. Menck 